\title{
Impact of Methyl Salicylate Lures on the Mint Aphid, Eucarazzia elegans (Hemiptera: Aphididae) Density and Natural Enemy Abundances in Common Sage Fields
}

\author{
A. Zarkani ${ }^{1}$ and F. Turanli ${ }^{2}$ \\ ${ }^{1}$ Department of Plant Protection, Faculty of Agriculture, University of Bengkulu, 383711, Bengkulu, Indonesia \\ ${ }^{2}$ Department of Plant Protection, Faculty of Agriculture, Ege University, 35100, Izmir, Turkey \\ ${ }^{1}$ Corresponding authore-mail: agustinzarkani@unib.ac.id
}

\begin{abstract}
Methyl Salicylate (MeSA) could be naturally produced by plants as an herbivore-induced plant volatile (HIPV) for attracting natural enemies as well as inhibiting herbivore populations. This study evaluated the attractiveness of synthetic MeSA lures to the natural enemies and its impact on Eucarazzia elegans (Hemiptera: Aphididae) population as a potential pest in common sage plants (Salvia officinalis L.). MeSA lures were distributed in the experimental fields then sticky yellow traps were used to measure the natural enemy abundances in the treated and untreated blocks. The effect of MeSA on E. elegans population in with and without the absence of natural enemies were conducted in the semi-field while the impacts of MeSA on E. elegans growth were evaluated in the laboratory. According to results, several numbers of natural enemies: Chantaridae, Coccinellidae (Coleoptera), Syrphidae (Diptera), and Chrysopidae (Neuroptera) were abundantly caught on traps adjacent to the MeSA odors. Moreover, the abundance of E. elegans in MeSA-treated blocks was significantly lower than untreated blocks. In semi-field experiments, the aphid populations were significantly reduced on treated common sage plants when it exposed to the natural enemies in the $2^{\text {nd }}$ and $3^{\text {rd }}$ week after MeSA deployment. In laboratory condition, the aphid growth rates undertreated and untreated were not different implicating no effects of MeSA on aphid population and emphasizing the role of natural enemies in the aphid control.
\end{abstract}

Keywords: Eucarazzia elegans, Herbivore-induced plant volatile, Methyl salicylate, Salvia officinalis

\section{INTRODUCTION}

Attacking of herbivorous arthropods, microbial pathogens, or even mechanical injuries on plants often respond producing a bouquet of volatiles [1], [2]. This volatiles well-known as volatile oil compounds (VOCs) or herbivore-induced plant volatiles (HIPVs) can effect directly on the intruders and serve as signals within and between plants [3], [4]. At the third trophic level, the information encoded by the blend of the HIPV molecules is used by predators to locate its prey [5] or lies in the attraction of predators of herbivores [6]. HIPVs also shows an indirect effect to herbivore species since its chemical compound can only arise via the plant as an intermediate organism [7]-[9].

One of VOC's is the phenolic compound, methyl salicylate (MeSA) [10] which has been identified in the herbivore-induced volatile blends from some plants such as potato [11], tomato [12], [13], and rice [10]. Ozawa et al., (2000) demonstrated lima bean leaves attacked by spider mite produced a blend of volatiles which was similar to MeSA. Wild tobacco, Nicotiana attenuata, damaged by three species of leaf-feeding herbivores released MeSA emission [15], as did two other plants namely, Datura stramonium and Robinia pseudoacacia when attacked by the spider mite, Tetranychus urticae [11]. Two common plant species of Betulaceae family, Betula pendula and Alnus glutinosa emitted MeSA when infested by specialist aphid species Euceraphis betulae under laboratory conditions [16]. Evenly, tobacco plants which were inoculated with tobacco mosaic virus also produced MeSA [17].

The evidence for the attraction of natural enemies to MeSA as HIPVs are needed to an extent in some studies [18]. Laboratory studies have demonstrated plant MeSA volatile to be positively attractive to the predatory mites, Typhlodromus pyri [19] Phytoseiulus persimilis [20], [21], and the predatory bug, Anthocoris nemoralis [22]. Insect predators attracted to MeSA included Coccinella septempunctata [23], Chrysopa nigricornis [4] and Geocoris pallens [24] were reported. Similarly, the 
great numbers of green lacewings and syrphid flies were caught on traps with MeSA emitters [25], [26].

In contrast, MeSA badly impacts to some insect pests in the laboratory [27] and in the field conditions [28], [29]. In behavioral studies using olfactometer, MeSA compound was repellent to Aphis fabae and also inhibited attraction to volatiles from its host, broad bean Vicia faba [27]. The presence of MeSA negatively affected attraction and changed the host-finding behavior of the parasitoid Diadegma semiclausum which tended to avoid MeSA-emitting plant. [30]. Female pine weevils, Hylobius abietis is known for adding frass containing fungi Ophiostoma pluriannulatum to the eggs that emit MeSA as repellent volatiles for the other pine weevils [31]. MeSA emitters also caused bad effect on Pieris brassicae butterflies which laid fewer eggs on host plant Arabidopsis deployed besides the plants with constitutively high MeSA vapor [32]. The residence time of thrips Frankliniella occidentalis was known significantly shorter on the leaf treated with $1 \%$ MeSA compared the control [33]. It also caused an oviposition deterrents for $F$. occidentalis females when threating on plum blossoms [34].

This study revealed the attractiveness of MeSA lures to the insect natural enemies and its impact on the mint aphid, Eucarazzia elegans (Hemiptera: Aphididae) as one of the key insect pests of common sage, Salvia officinalis L. The effectivity of the lures can be used to involve the biological control strategy toward integrated pest management on commercial sage plantings.

\section{MATERIALS AND METHODS}

\section{Methyl salicylate (MeSA) effect on aphids and natural enemies population in the field}

MeSA deployment. The lures were Predalure ${ }^{\circledR}$, AgBio, Westminster, slow-release lures $90 \mathrm{~d}$, contained MeSA $5 \mathrm{~g} \mathrm{pack}^{-1}$. The emitters were deployed in the sage fields at Field Crops Department, Agricultural Faculty, Ege University, Bornova, Izmir Province where no insect pest management treatments were applied. The experimental form consisted of one hectare of 3 years-old $S$. officinalis which was harvested six months before and had grown new aerial parts. A randomized complete block design with 12 pairs (treated and untreated MeSA lure) of plots ( $3 \times 2$ $\mathrm{m})$ was used in the experiment. Treated and untreated MeSA lure plots were placed about $20 \mathrm{~m}$ apart within each pair and $5 \mathrm{~m}$ from any field edge. One package of MeSA emitter was hung at the plant canopy height on each treated plot. The lures were set up on the first of March 2017, a week after the emergence of aphids on the sage plant, and evaluated every week until the end of May.

Collection of natural enemies. A yellow sticky card trap (Rebell $^{\circledR}$ Amarillo, Agroscope Changins-Wadenswil) was deployed at canopy height as staked $0.7 \mathrm{~m}$ above ground over and placed in the center of a selected plant in the plot together with the MeSA emitter or alone in untreated plots. The trap was installed about 12 replications in the sage field throughout the growing season from March to April 2017 , and on each occasion left in the field for 3 days before collection. All natural enemies trapped on the sticky card traps were collected and identified to family or species level. At the same time, the number of the mint aphids per plant were counted. Especially in the first week of MeSA deployment, the insects trapped were recorded daily along 4 days to analyze insect behaviors attracted by the lures.

\section{Methyl salicylate effect on aphids population growth in laboratory}

An experimental laboratory was used to evaluate the potential direct effects of MeSA on the aphids population growth. Two plants, S. officinalis were planted in each a $25 \mathrm{~cm}$-diameter plastic pot and kept in care until 60 days old in the greenhouse. The first instar nymphs were infested on the preexperimental sage plants. When the second generation of aphids reproduced nymphs, for each experimental plant, two first-instar nymphs ( $<6$ hours old) from the monoclonal colony was placed individually on each sage plant and then separated into the different places ( 25 pots treated and 25 pots untreated) under a similar condition at the temperature of $25 \pm 2^{\circ} \mathrm{C}, 65 \pm 5 \% \mathrm{RH}$ and $16 \mathrm{~h} \mathrm{~L}: 8 \mathrm{~h}$ D photoperiod. All treated sage plants were exposed to MeSA lure that placed and installed in the middle of all pot positions while untreated plants had similar methods with no lures. The experiments were conducted until the last aphid died. Data were recorded on daily basis to investigate aphid development and fertility.

Aphid growth population was calculated using the Jackknife technique [35]. The fertility life table with some parameters and formulas: 1) net reproductive rate $\left.\left(R_{o}\right), 2\right)$ intrinsic rate of increase $\left(r_{m}\right)$, 3 ) mean generation $(T)$, and 4 ) finite rate of increase $(\lambda)$ were used to evaluate the growth rate using following formulas:

$$
\begin{aligned}
& R_{o}=L_{x} \times m_{x} \\
& r_{m}=\frac{L n\left(R_{o}\right)}{t} \\
& T=\frac{\operatorname{Ln}\left(R_{o}\right)}{r_{m}} \\
& \lambda=e^{r_{m}}
\end{aligned}
$$

Where $L_{x}$ is the total female survivorship at each pivotal age, $m_{x}$ is the number of female offsprings coming from all females of the group at each pivotal age $x, t$ is generation time, and $T$ is the mean time span between the birth of individuals of a generation and that of the next generation.

\section{Methyl salicylate effect on aphids population growth in semi-field}

An identical procedure with laboratory test was applied on the semi-field experiment. Here, 500 last instar/aptera aphids were infested on each pot of the sage plant. A total of 84 pair pots consisted of treated and untreated plants paired with each 
treatment of uncaged and caged plant pots (arena was covered by $200-\mathrm{m}$ mesh Lumite screening, $4 \times 3 \times 1.5$ $\mathrm{m})$ that arranged separately in the field. The pots were placed in the field for 4 weeks with $20 \mathrm{~m}$ distance between the treated and untreated. Finally, aphids population was counted in each pot. Taxa of natural enemies, the number and presence time in each treatment were also recorded.

Statistical Analyses. Differentiation of the natural enemies and aphid population numbers on all treatments in the field experiment was analyzed with mixed model ANOVA. Treatments, time and the interaction between variables were set up as fixed effects while random effects included plot grouped within a block, and time was treated as the repeated variable. Whereas in the laboratory and semi-field experiment, differences in aphid densities were analyzed with ANOVA.

The natural enemies responses on all treatments were measured by biocontrol service index (BSI) described by Gardiner et al. (2009). This index was calculated in every two weeks by comparing the abundance population between caged and uncaged plants on MeSA treated and untreated plants by the following equation:

$$
B S I=\frac{\sum_{n=1}^{26} \frac{\left(A_{c, n}-A_{o, n}\right)}{A_{c, n}}}{n}
$$

\section{RESULTS}

\section{Effect of methyl salicylate lures on natural enemies in the field}

Although natural enemies were frequently found on the yellow sticky traps in all treatments during sampling time in 2017 growing seasons, its number trapped on treated plants exposed to the methyl salicylate (MeSA) lures was significantly higher than untreated plots $(\mathrm{F}=56.1 ; \mathrm{df}=1 ; \mathrm{P}<0.000)$. There was also a significant time $\times$ treatment interaction $(\mathrm{F}=10.6$; $\mathrm{df}=2 ; \mathrm{P}<0.000)$ in which the differences in natural enemy abundances were obviously high in April (Table 1 and Figure 1).

Table 1. The average of natural enemies trapped on yellow sticky traps in MeSA treated and untreated plots in sage fields over three months periods of growing season, 2017

\begin{tabular}{|c|c|c|c|c|c|}
\hline \multirow{2}{*}{ Natural enemies } & \multirow{2}{*}{ Treatment } & \multirow{2}{*}{$\begin{array}{c}\text { Number / Trap } \\
(\text { Mean } \pm \text { SEM) }\end{array}$} & \multicolumn{3}{|c|}{ ANOVA } \\
\hline & & & Treatment & Time & $\begin{array}{l}\text { Treatment- } \\
\text { Time }\end{array}$ \\
\hline \multirow{2}{*}{ Syrphidae (Diptera) } & $\mathrm{MeSA}$ & $5.571 \pm 0.612$ & \multirow{2}{*}{$\begin{array}{l}\mathrm{F}=23.67 \\
\mathrm{P}=0.000 * * *\end{array}$} & \multirow{2}{*}{$\begin{array}{l}\mathrm{F}=1.83 \\
\mathrm{P}=0.176\end{array}$} & \multirow{2}{*}{$\begin{array}{l}\mathrm{F}=3.39 \\
\mathrm{P}=0.045^{*}\end{array}$} \\
\hline & Control & $0.857 \pm 0.261$ & & & \\
\hline \multirow{2}{*}{ Asilidae (Diptera) } & $\mathrm{MeSA}$ & $0.857 \pm 0.553$ & \multirow{2}{*}{$\begin{array}{l}\mathrm{F}=1.34 \\
\mathrm{P}=0.255\end{array}$} & \multirow{2}{*}{$\begin{array}{l}F=0.70 \\
P=0.505\end{array}$} & \multirow{2}{*}{$\begin{array}{l}\mathrm{F}=0.70 \\
\mathrm{P}=0.505\end{array}$} \\
\hline & Control & $0.143 \pm 0.143$ & & & \\
\hline \multirow{2}{*}{$\begin{array}{l}\text { Rhagonycha fulva } \\
\text { (Coleoptera) }\end{array}$} & $\mathrm{MeSA}$ & $6.143 \pm 1.262$ & \multirow{2}{*}{$\begin{array}{l}\mathrm{F}=27.60 \\
\mathrm{P}=0.000 * * *\end{array}$} & \multirow{2}{*}{$\begin{array}{l}\mathrm{F}=20.61 \\
\mathrm{P}=0.000 * * *\end{array}$} & \multirow{2}{*}{$\begin{array}{l}\mathrm{F}=20.61 \\
\mathrm{P}=0.000 * * *\end{array}$} \\
\hline & Control & 0 & & & \\
\hline \multirow{2}{*}{$\begin{array}{l}\text { Coccinella septempuctata } \\
\text { (Coleoptera) }\end{array}$} & $\mathrm{MeSA}$ & $5.143 \pm 0.857$ & \multirow{2}{*}{$\begin{array}{l}\mathrm{F}=13.40 \\
\mathrm{P}=0.001 * *\end{array}$} & \multirow{2}{*}{$\begin{array}{l}\mathrm{F}=17.10 \\
\mathrm{P}=0.000 * * *\end{array}$} & \multirow{2}{*}{$\begin{array}{l}\mathrm{F}=7.90 \\
\mathrm{P}=0.001 * *\end{array}$} \\
\hline & Control & $1.000 \pm 0.577$ & & & \\
\hline \multirow{2}{*}{$\begin{array}{l}\text { Hippodamia variegata } \\
\text { (Coleoptera) }\end{array}$} & $\mathrm{MeSA}$ & $0.286 \pm 0.286$ & \multirow{2}{*}{$\begin{array}{l}\mathrm{F}=0.00 \\
\mathrm{P}=1.000\end{array}$} & \multirow{2}{*}{$\begin{array}{l}F=0.710 \\
P=0.50\end{array}$} & \multirow{2}{*}{$\begin{array}{l}\mathrm{F}=2.12 \\
\mathrm{P}=0.135\end{array}$} \\
\hline & Control & $0.286 \pm 0.184$ & & & \\
\hline \multirow{2}{*}{$\begin{array}{l}\text { Coccinella bipunctata } \\
\text { (Coleoptera) }\end{array}$} & $\mathrm{MeSA}$ & $0.143 \pm 0.143$ & \multirow{2}{*}{$\begin{array}{l}\mathrm{F}=1.00 \\
\mathrm{P}=0.324\end{array}$} & \multirow{2}{*}{$\begin{array}{l}\mathrm{F}=1.00 \\
\mathrm{P}=0.378\end{array}$} & \multirow{2}{*}{$\begin{array}{l}\mathrm{F}=1.00 \\
\mathrm{P}=0.378\end{array}$} \\
\hline & Control & $0.243 \pm 0.143$ & & & \\
\hline \multirow{2}{*}{ Scymus sp. (Coleoptera) } & $\mathrm{MeSA}$ & $0.429 \pm 0.297$ & \multirow{2}{*}{$\begin{array}{l}F=0.20 \\
P=0.657\end{array}$} & \multirow{2}{*}{$\begin{array}{l}F=3.20 \\
P=0.053\end{array}$} & \multirow{2}{*}{$\begin{array}{l}F=0.20 \\
P=0.820\end{array}$} \\
\hline & Control & $0.714 \pm 0.565$ & & & \\
\hline \multirow{2}{*}{$\begin{array}{l}\text { Exochomus nigromaculatus } \\
\text { (Coleoptera) }\end{array}$} & $\mathrm{MeSA}$ & $0.286 \pm 0.184$ & \multirow{2}{*}{$\begin{array}{l}\mathrm{F}=0.33 \\
\mathrm{P}=0.570\end{array}$} & $\mathrm{~F}=1.00$ & $\mathrm{~F}=0.33$ \\
\hline & Control & $0.143 \pm 0.143$ & & $\mathrm{P}=0.378$ & $\mathrm{P}=0.719$ \\
\hline D. & $\mathrm{MeSA}$ & $0.857 \pm 0.460$ & $\mathrm{~F}=0.02$ & $\mathrm{~F}=1.10$ & $\mathrm{~F}=2.04$ \\
\hline Braconidae (Hymneoptera) & Control & $1.000 \pm 0.845$ & $\mathrm{P}=0.882$ & $\mathrm{P}=0.345$ & $\mathrm{P}=0.145$ \\
\hline Phaeostigma notata & $\mathrm{MeSA}$ & $0.857 \pm 0.460$ & $\mathrm{~F}=2.34$ & $\mathrm{~F}=2.91$ & $\mathrm{~F}=1.22$ \\
\hline (Neuroptera: Raphidiidae) & Control & $0.143 \pm 0.143$ & $\mathrm{P}=0.135$ & $\mathrm{P}=0.068$ & $\mathrm{P}=0.308$ \\
\hline Chrysoperla carnea & $\mathrm{MeSA}$ & $0.857 \pm 0.460$ & $\mathrm{~F}=21.14$ & $\mathrm{~F}=2.91$; & $\mathrm{F}=1.22$ \\
\hline (Neuroptera: Chrysopidae) & Control & $0.024 \pm 0.008$ & $\mathrm{P}=0.001 * *$ & $\mathrm{P}=0.008 * *$ & $\mathrm{P}=0.001 * *$ \\
\hline
\end{tabular}

Treatment $\mathrm{df}=1 ;$ time $\mathrm{df}=2 ;$ and time-treatment $\mathrm{df}=2$ 
Here $A c$ is the final number of aphids on caged plants, $A o$ is the final number of aphids on uncaged plants, and $n$ is the number of replicates or pairs of caged and uncaged plants.

Among natural enemies trapped, the taxa Rhagonycha fulva (Coleoptera: Chantaridae), Syrphidae (Diptera), Coccinella septempuctata (Coleoptera: Coccinellidae) and Chrysoperla carnea (Neuroptera: Chrysopidae) were the most abundant in the MeSA treated plots compared to untreated plots, respectively (Table 1 and Figure 2). In specific, Syrphidae and $R$. fulva were much plentiful in April while $C$. septempuctata and $C$. carnea were abundant in March. Other entomophagous insects such as Hippodamia variegata, Exochomus nigromaculatus, Coccinella bipunctata (Coleoptera: Coccinellidae), Chrysoperla carnea (Neuroptera: Chrysopidae) and Phaeostigma notata (Neuroptera: Raphidiidae) were less dominant species trapped on the yellow sticky cards. Interestingly, some insect species; Scymus sp., $C$. bipunctata (Coleoptera: Coccinellidae) and some parasitoid Braconidae (Hymenoptera) were trapped more in the untreated plots (control) than MeSA treated plots.

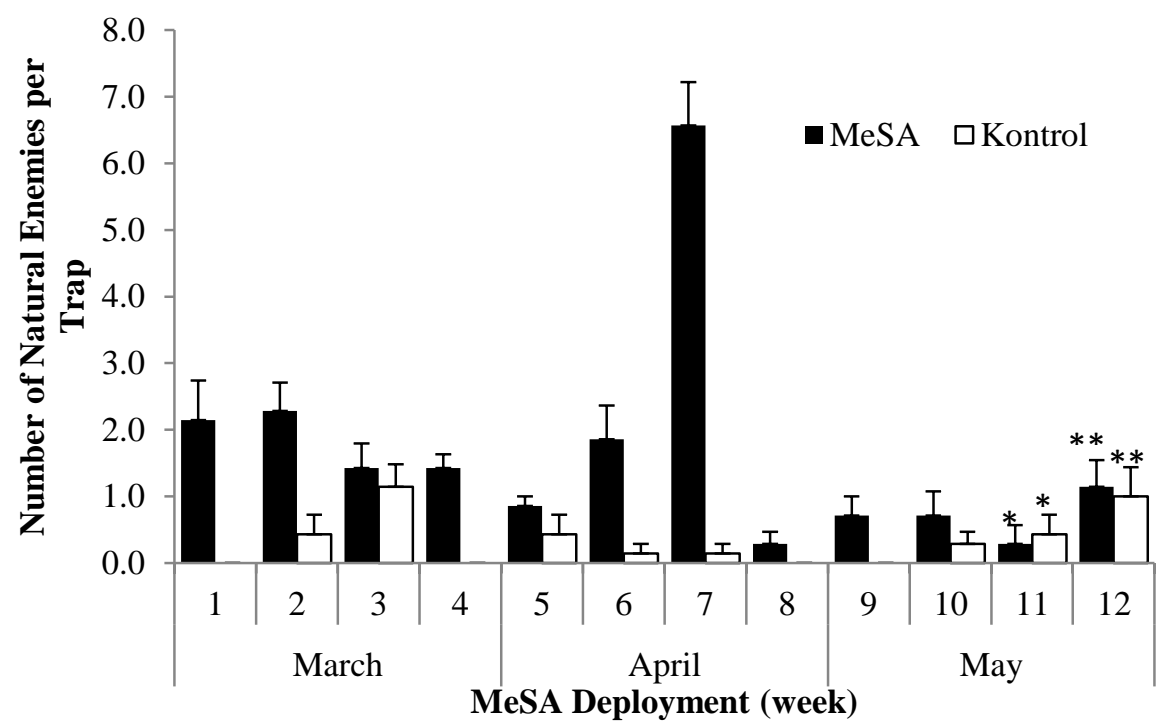

Figure 1. Average of natural enemies trapped, means \pm SEM, per 4-d period in MeSA treated and untreated plots in the sage fields over three months periods of growing season, March to May 2017.

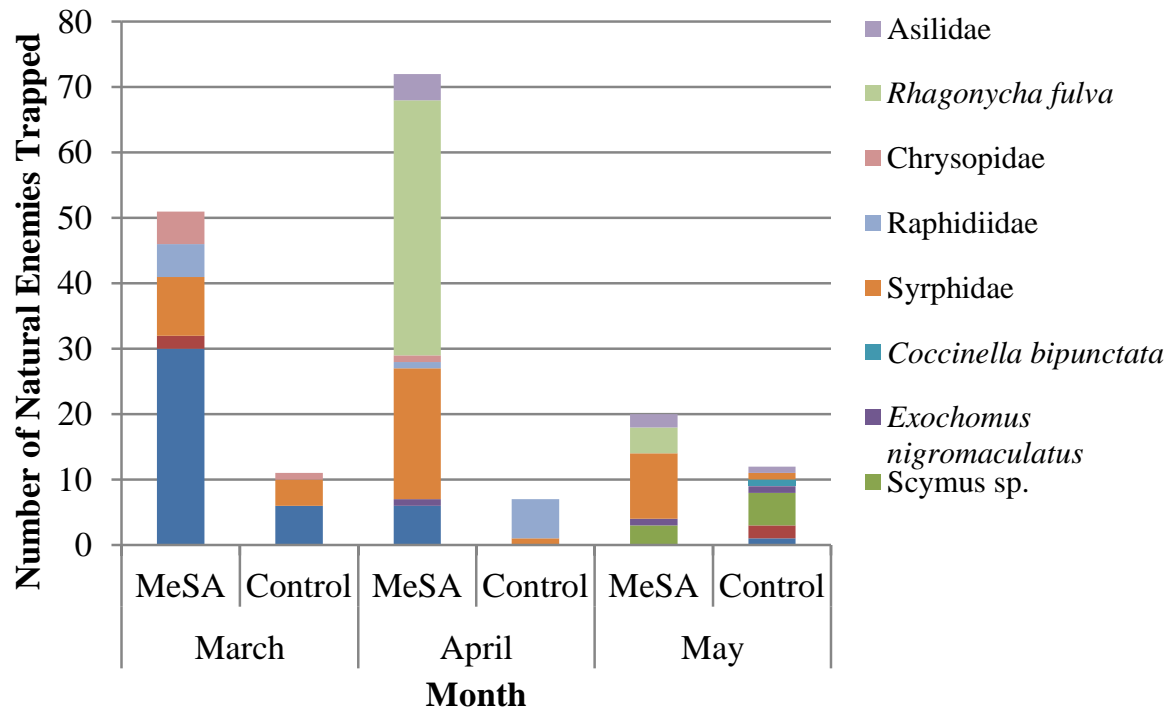

Figure 2. A composition of natural enemies trapped in MeSA treated and untreated along three months experiment in growing season, 2017.

Along with a four-day observation, the insect's taxa visited the lures on the first day respectively were Syrphidae, $C$. septempuctata, $H$. variegata and Asilidae (Figure 3). In the remain days, the first two species were consistently trapped at 08:00 - 09:00 a.m. and then followed by other insects taxa after 09:00 a.m. in random time. 


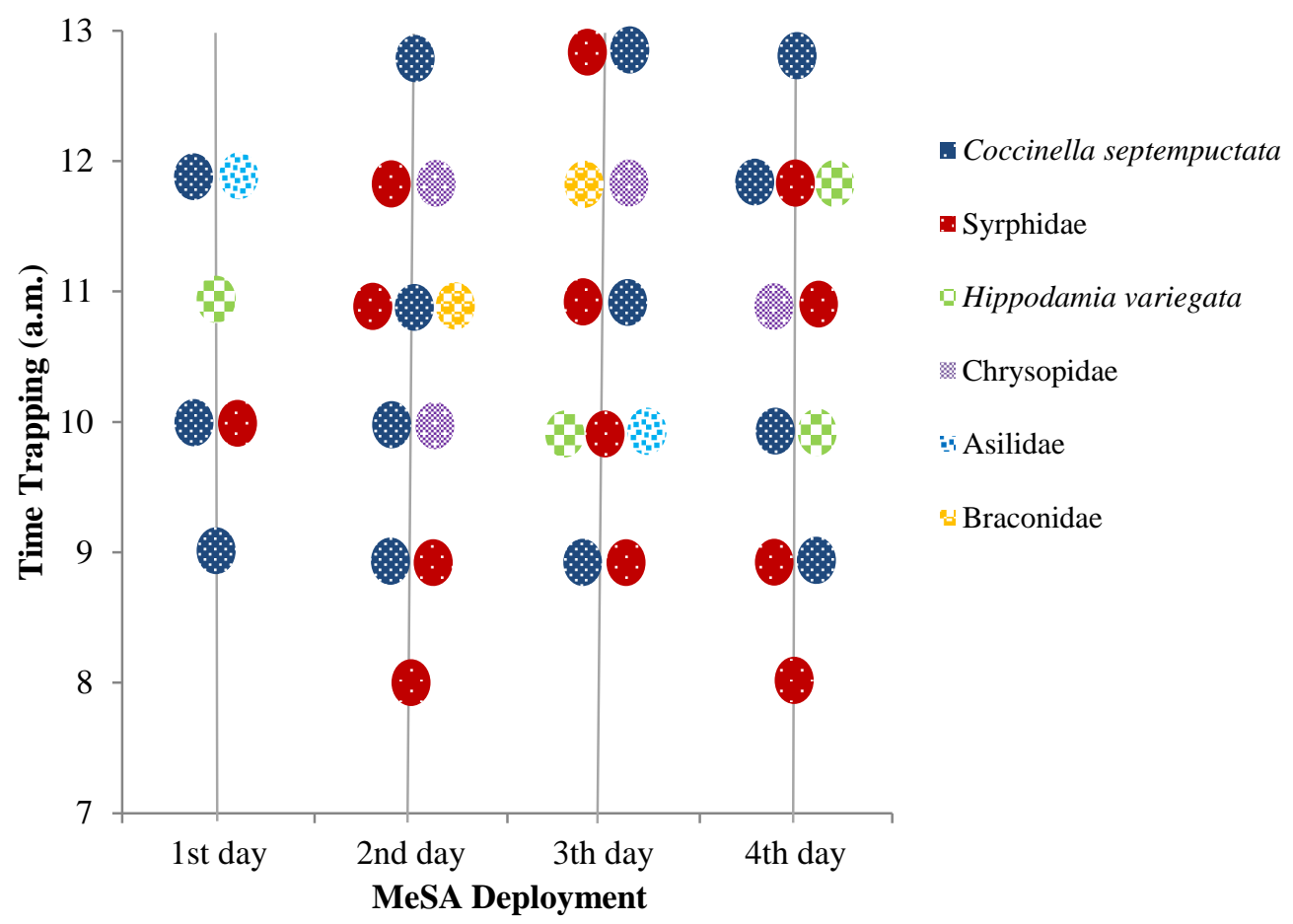

Figure 3. Behavioral natural enemies trapped in MeSA treatment during four days experiment, observation time 07:00 a.m to 13:00 a.m.

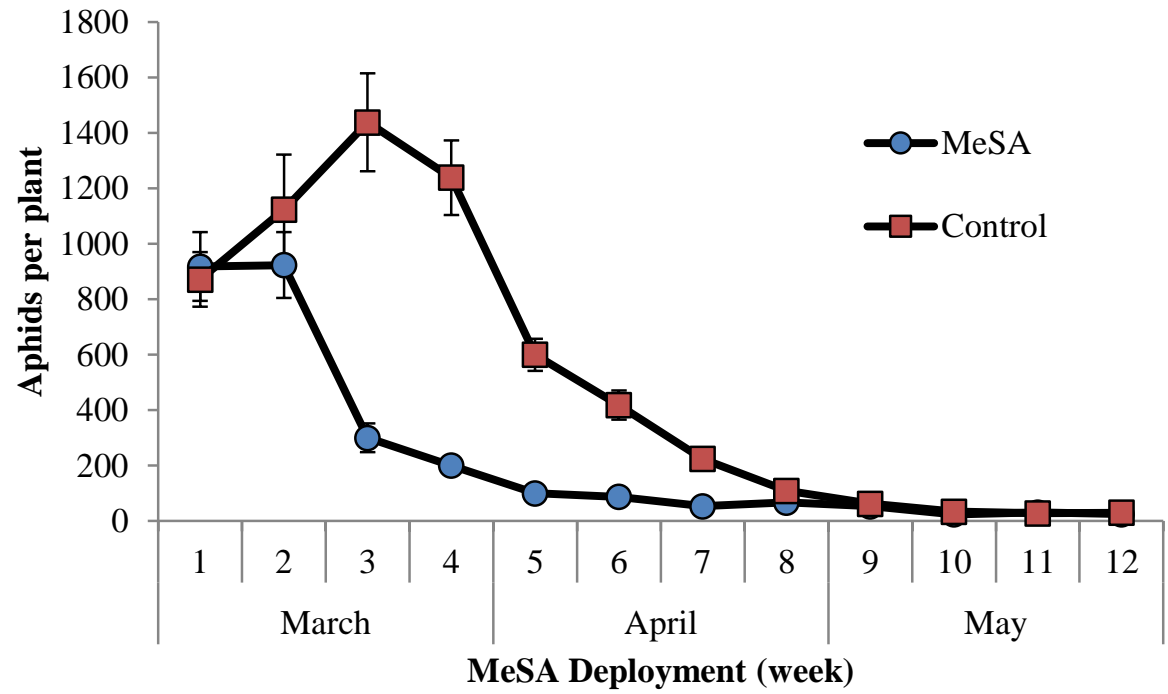

Figure 4. Average of the mint aphid, Eucarazzia elegant population per plant (means \pm SEM) in MeSA treated and untreated plots during the growing season in 2017.

The aphid populations in the treated plots were significantly different compared with untreated plots $(\mathrm{F}=49$; $\mathrm{df}=1 ; \mathrm{P}<0.011$; Figure 4). However, it showed that there was no significant time $\times$ treatment interaction $(\mathrm{F}=1.5 ; \mathrm{df}=1 ; \mathrm{P}<0.56)$.

Impact of methyl salicylate on aphid population growth in the laboratory
The response of aphids population in laboratory condition without natural enemy attendances on MeSA resulted no statistical differences in all lifetable parameters included aphid finite rate of population increase $(\lambda)$, intrinsic rate of population increase $(r)$, net reproductive rate $\left(R_{o}\right)$, and mean generation time $(\mathrm{T})$. It was clear that there was consistency as well shown between $T$ and $R_{0}$ value in both treatments (Table 2). 
Table 2. Life table parameters of an adult aphid Eucarazzia elegans raised in the laboratory on methyl salicylate treated and untreated sage plants on 20 days

\begin{tabular}{|l|c|c|c|c|}
\hline Treatment & T $( \pm$ SEM $*)$ & $\mathbf{R}_{\mathbf{0}}( \pm$ SEM $)$ & $\mathbf{r}( \pm$ SEM $)$ & $\boldsymbol{\lambda}( \pm$ SEM $)$ \\
\hline MeSA & $9.36 \pm 0.99 \mathrm{a}^{* *}$ & $21.80 \pm 0.72 \mathrm{a}$ & $0.357 \pm 0.026 \mathrm{a}$ & $1.438 \pm 0.036 \mathrm{a}$ \\
\hline Control & $9.37 \pm 1.10 \mathrm{a}$ & $21.65 \pm 1.16 \mathrm{a}$ & $0.351 \pm 0.065 \mathrm{a}$ & $1.425 \pm 0.045 \mathrm{a}$ \\
\hline
\end{tabular}

* SEM: Standard error of the mean;

** Means in a column followed by the same letter are not statistical significantly different (ANOVA P $<0.05$, Tukey's test).

Effects of methyl salicylate on aphid population in the semi-field

Semi-field experiment on aphids population rate in the caged arena revealed that the aphid densities in the untreated plots were not significantly higher than treated plots $(\mathrm{F}=1.52 ; \mathrm{df}=1.14 ; \mathrm{P}=0.45)$. In open cage arena, however, its were significantly different at 14 th dan 21st day after MeSA deployed ( $\mathrm{F}=4.2$; df $=1.14$; $\mathrm{P}=0.02$ ) but not significantly different at the 28th-day observation $(\mathrm{F}=0.39 ; \mathrm{df}=1.14 ; \mathrm{P}=0.32)$. The aphid population in the plants exposed to MeSA treatment decreased sharply starting after the second week and then it would be near to same level population at the last week of the experiment (Figure 5a).

When the experiments were conducted in a cage, the number of the mint aphid population were not significantly different $((\mathrm{F}=1.8 ; \mathrm{df}=1.14 ; \mathrm{P}<0.63$; Figure $6 \mathrm{~b})$. Here, the aphid population tends to increase gradually in every week observation before it decreased slowly in the next two-week.
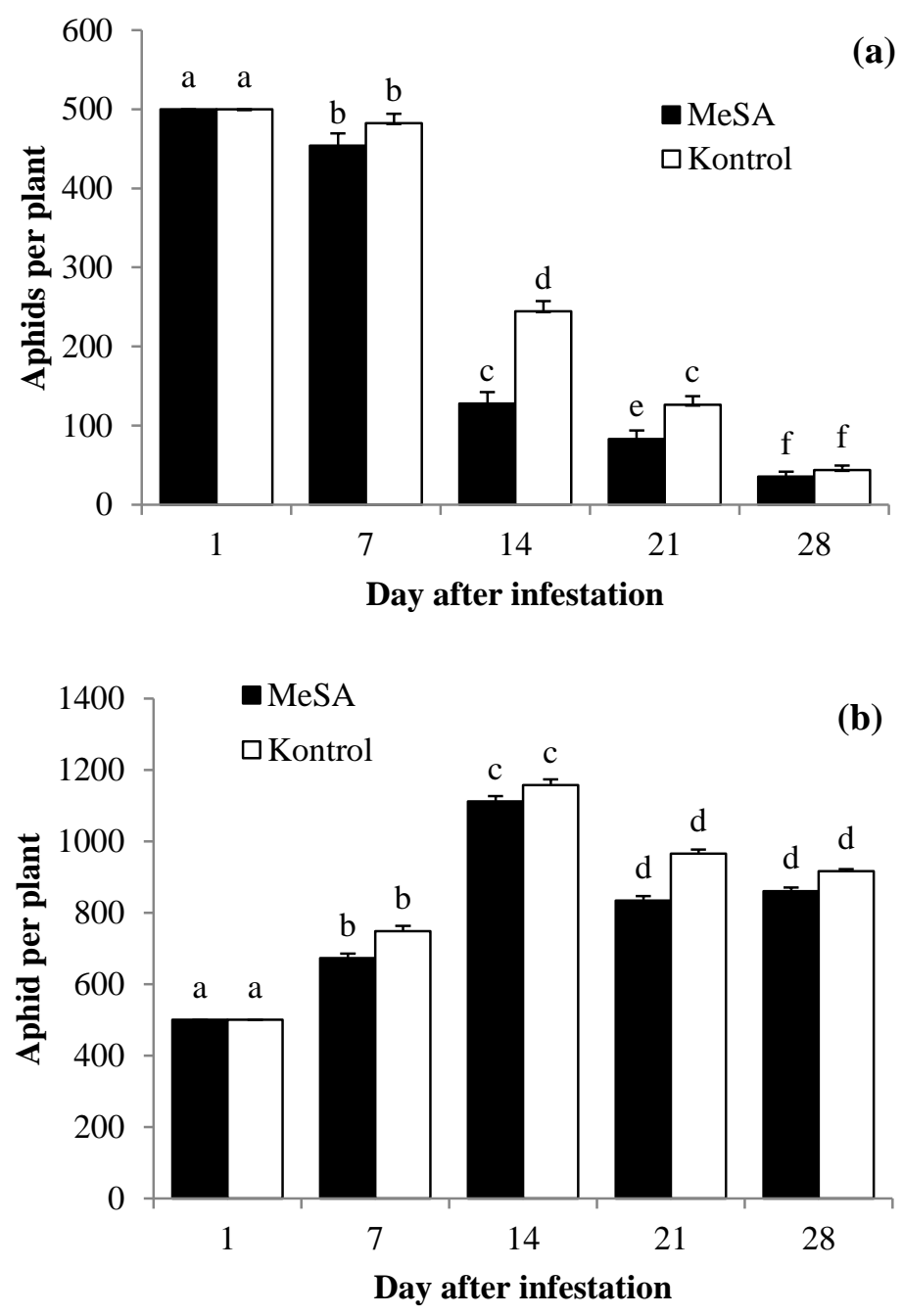

Figure 5. Average abundance, means \pm SEM, of aphid Eucarazzia elegans per plant in MeSA treated and untreated plots in the open caged (a) and caged (b), semi-fields experiment. 
The functional activity level of natural enemies calculated by biocontrol service index (BSI) in two weeks after deployment in all experimental plots were 0.9410 and 0.7810 , respectively. These indexes were marginally different with the BSI index taken after fourth-week at the same plots where MeSA treated had 0.9610 and untreated 0.9510 BSI. The natural enemies mostly presenced on the aphid population in the semi-field study were $C$. septempuctata, $H$. variegata, Syrphidae and spiders.

\section{DISCUSSION}

Herbivore-induced plant volatiles (HIPVs) have been important plant molecules as it knowingly influencing plant-insect interactions through changed feeding performance and host plant preference, or by influencing third trophic level [6], [37]. In this study, methyl salicylate (MeSA) as one of the HIPVs revealed the role with significantly attraction natural enemies in which the predatory insect taxa were most trapped. Generally, MeSA attracts the abundant predatorious insects from Coleoptera, Diptera and Neuroptera order [18]. In fact, the strongest attraction to MeSA was shown in the natural enemy group taxa R. fulva (Coleoptera) and Syrphid flies, which both adults do not feed on aphids but rather on pollen and nectar. Other predators such as $C$. semptempunctata, C. carnea were a large predatorius insect distributed worldwide that are predator as an adult as well as a larva.

The taxa of $C$. septempuctata, $H$. variegata, Syrphidae, Chrysopidae and Asilidae showed a quick response to the lure which the insects were attracted in the first 4-day. Unfortunately, ladybird $H$. variegata the green lacewing $C$. carnea known as potential aphid natural enemies were trapped in small number that has not been implicated as having strong effects on the aphid populations in this study.

MeSA emitters just strongly allured natural enemies in the first two-month before decreased at the same level with control for the next month. Lack of MeSA effects appeared in the field during May, compared to March-April where its strong odor was obvious. The effects of MeSA in the first developing time was important in which the early attendance of natural enemies into the agroecosystem could be an effective biological strategy for controlling insect pest populations [38]. The atmospheric concentrations of MeSA in this study may have been excessively stimulating to an attraction of predators in the field, during the experimental time.

The pattern of attractiveness showed that the flying insects were much dominant collected. A large number of the natural enemies trapped in this experimental study may also reveal the real insect's composition in the habitat. Interestingly, some predators trapped in the control or untreated were not only impacted by MeSA attraction but also attracted by yellow color. This study recorded some ladybird beetles and parasitoid Braconidae that mostly trapped in the control without MeSA treatment. It probably means yellow trap effect to change the insect's orientations. Another evidence was showed by abundant leafhopper (Hemiptera: Cicadellidae), the insect attracted to yellow, trapped in both treated and untreated sticky yellow trap. It proved that the yellow sticky traps could be dangerous to some beneficial insects.

The study also found bees and butterflies in a small number on both MeSA treated and untreated traps that indicated there was no side effect in pollinators foraging. Dosage and composition in MeSA treatment have to be considered when it was related to flowering plants due to its influence on the pollinators. Mayer (1997) reported that the applications of MeSA lures at the high concentration could reduce honey bee foraging. It has been important since pollinator insect poisoning from pesticides is a serious problem worldwide.

Over the first day observation, $C$. septempunctata was among the first attraction by MeSA followed by Syrphidae and then $H$. variegata. This was similar to previous studies that demonstrated the attraction of these groups to MeSA in nature [23], [26]. The attractiveness of natural enemies by the time was different because of MeSA degradation and seasonal time impact. Insects adaptation and learning habit may influence the results.

MeSA has weak to no effect on mint aphid E. elegans development, with an assumption of the value of all life table parameter failed to describe a consistent pattern on both treatments. Unfortunately, how far the antifeedant effect of MeSA emitter worked to suppress aphid population was not calculated. It can presumably result in multiple mechanisms that MeSA increasing the emigration of aphids.

The biocontrol service index (BSI) reveals a varying scale between 0.0 to 1.0 on which the indexes were changed with the values increasing as the level of aphid predation increases. The BSI index surely grew up near to scale 1.0 started in the first a twoweek period which indicates the role of natural enemies was running well and the attractiveness of MeSA was rolling as well in the experimental fields. About two weeks were needed for natural enemies to find their prey without the influence of MeSA appeal. This time-related attractiveness was almost same with the experiment conducted by Mallinger et al. (2011).

This research provided some shreds of evidence that the use of synthetic MeSA in an agroecosystem can stimulate recruitment and residency of some beneficial insects in order to improve biological control. In this case, generalist predators such as lady beetle, lacewings, and hoverflies, as well as some spider mite predators are key players in early season biological control of aphids on plants. Recruitment of natural enemies to the field during early springtime may provide a way of increasing their reliability and abundances for protecting the plant in the growing seasons. 


\section{CONCLUSION}

Methyl Salicylate (MeSA) lures attract several numbers of natural enemies such as Chantaridae, Coccinellidae (Coleoptera), Syrphidae (Diptera), and Chrysopidae (Neuroptera). The abundance of $E$. elegans in MeSA-treated was significantly lower than untreated ones. In semi-field experiments, E. elegans populations were significantly reduced on treated plants when exposed to the natural enemies in the $2^{\text {nd }}$ and $3^{\text {rd }}$ week after MeSA deployment. In laboratory conditions, the aphid growth rates undertreated and untreated were not different implicating no effects of MeSA on aphid population and emphasizing the role of natural enemies in the aphid control.

\section{ACKNOWLEDGMENT}

The authors are grateful to Dr. Ian Timothy Riley, Anhui Academy of Agricultural Science, China, for critical reading of the manuscript.

\section{REFERENCES}

[1] A. Janssen, M. W. Sabelis, and J. Bruin, 'Evolution of herbivore-induced plant volatiles', Oikos, vol. 97, no. 1, pp. 134-138, 2002.

[2] R. A. Sarmento et al., 'A herbivore that manipulates plant defence: A herbivore that manipulates plant defence', Ecol. Lett., vol. 14, no. 3, pp. 229-236, Mar. 2011, doi: 10.1111/j.1461-0248.2010.01575.x.

[3] D. J. Ballhorn, S. Kautz, U. Lion, and M. Heil, 'Trade-offs between direct and indirect defences of lima bean (Phaseolus lunatus): Trade-off between cyanogenesis and VOCemission', J. Ecol., vol. 96, no. 5, pp. 971980, Sep. 2008, doi: 10.1111/j.13652745.2008.01404.x.

[4] D. G. James, 'Field evaluation of herbivoreinduced plant volatiles as attractants for beneficial insects: methyl salicylate and the green lacewing, Chrysopa nigricornis', J. Chem. Ecol., vol. 29, no. 7, pp. 1601-1609, 2003.

[5] P. W. Price, C. E. Bouton, P. Gross, B. A. McPheron, J. N. Thompson, and A. E. Weis, 'Interactions among three trophic levels: influence of plants on interaction between insect herbivores and natural enemies', Ecol. Syst., vol. 11, pp. 41-65, 1980.

[6] M. Gish, C. M. De Moraes, and M. C. Mescher, 'Herbivore-induced plant volatiles in natural and agricultural ecosystems: open questions and future prospects', Curr. Opin. Insect Sci., vol. 9, pp. 1-6, Jun. 2015, doi: 10.1016/j.cois.2015.04.001.

[7] G. Arimura, C. Kost, and W. Boland, 'Herbivore-induced, indirect plant defences', Biochim. Biophys. Acta BBA - Mol. Cell Biol. Lipids, vol. 1734, no. 2, pp. 91-111, May 2005, doi: 10.1016/j.bbalip.2005.03.001.

[8] C. Kost, 'Herbivore-induced indirect plant defences of Lima bean (Phaseolus lunatus, Fabaceae)', Universidade Estadual de Campinas, 2006.

[9] T. Li, J. K. Holopainen, H. Kokko, A. I. Tervahauta, and J. D. Blande, 'Herbivoreinduced aspen volatiles temporally regulate two different indirect defences in neighbouring plants: VOC-mediated indirect defences in woody plants', Funct. Ecol., vol. 26, no. 5, pp. 1176-1185, Oct. 2012, doi: 10.1111/j.1365-2435.2012.01984.x.

[10] N. Zhao et al., 'Biosynthesis and emission of insect-induced methyl salicylate and methyl benzoate from rice', Plant Physiol. Biochem., vol. 48, no. 4, pp. 279-287, Apr. 2010, doi: 10.1016/j.plaphy.2010.01.023.

[11] C. E. Van Den Boom, T. A. Van Beek, M. A. Posthumus, A. De Groot, and M. Dicke, 'Qualitative and quantitative variation among volatile profiles induced by Tetranychus urticae feeding on plants from various families', J. Chem. Ecol., vol. 30, no. 1, pp. 69-89, 2004.

[12] K. Ament, V. Krasikov, S. Allmann, M. Rep, F. L. W. Takken, and R. C. Schuurink, 'Methyl salicylate production in tomato affects biotic interactions: Role of methyl salicylate in tomato defence', Plant J., vol. 62, no. 1, pp. 124-134, Apr. 2010, doi: 10.1111/j.1365-313X.2010.04132.x.

[13] D. Tieman et al., 'Functional analysis of a tomato salicylic acid methyl transferase and its role in synthesis of the flavor volatile methyl salicylate: Tomato transferase and synthesis of methyl salicylate', Plant J., vol. 62, no. 1, pp. 113-123, Apr. 2010, doi: 10.1111/j.1365-313X.2010.04128.x.

[14] R. Ozawa, G. Arimura, J. Takabayashi, T. Shimoda, and T. Nishioka, 'Involvement of jasmonate-and salicylate-related signaling pathways for the production of specific herbivore-induced volatiles in plants', Plant Cell Physiol., vol. 41, no. 4, pp. 391-398, 2000.

[15] A. Kessler and I. T. Baldwin, 'Defensive function of herbivore-induced plant volatile emissions in nature', Science, vol. 291, pp. 2141-2144, 2001. 
[16] J. D. Blande, M. Korjus, and J. K. Holopainen, 'Foliar methyl salicylate emissions indicate prolonged aphid infestation on silver birch and black alder', Tree Physiol., vol. 30, no. 3, pp. 404-416, Mar. 2010, doi: 10.1093/treephys/tpp124.

[17] V. Shulaev, P. Silverman, and I. Raskin, 'Airborne signalling by methyl salicylate in plant pathogen resistance', Nature, vol. 385, pp. 718-721, 1997.

[18] C. Rodriguez-Saona, I. Kaplan, J. Braasch, D. Chinnasamy, and L. Williams, 'Field responses of predaceous arthropods to methyl salicylate: A meta-analysis and case study in cranberries', Biol. Control, vol. 59, no. 2, pp. 294-303, Nov. 2011, doi: 10.1016/j.biocontrol.2011.06.017.

[19] A. N. Gadino, V. M. Walton, and J. C. Lee, 'Olfactory response of Typhlodromus pyri (Acari: Phytoseiidae) to synthetic methyl salicylate in laboratory bioassays: T. pyri response to methyl salicylate', J. Appl. Entomol., vol. 136, no. 6, pp. 476-480, Jul. 2012, doi: $\quad 10.1111 /$ j.14390418.2011.01670.x.

[20] J. G. De Boer and M. Dicke, 'Experience with methyl salicylate affects behavioural responses of a predatory mite to blends of herbivore-induced plant volatiles', Entomol. Exp. Appl., vol. 110, no. 2, pp. 181-189, 2004.

[21] S. K. Shastani, M. Ziaaddini, M. Latifi, and A. Z. Golpayegani, 'Olfactory response of predatory mite Phytoseiulus persimilis to synthetic methyl salicylate', Arch. Phytopathol. Plant Prot., vol. 47, no. 20, pp. 2442-2446, Dec. 2014, doi: $10.1080 / 03235408.2014 .880562$.

[22] B. Drukker, J. Bruin, and M. W. Sabelis, 'Anthocorid predators learn to associate herbivore-induced plant volatiles with presence or absence of prey', Physiol. Entomol., vol. 25, no. 3, pp. 260-265, Sep. 2000, doi: $\quad 10.1046 / \mathrm{j} .1365-$ 3032.2000.00190.x.

[23] J. Zhu and K.-C. Park, 'Methyl Salicylate, a Soybean Aphid-Induced Plant Volatile Attractive to the Predator Coccinella septempunctata', J. Chem. Ecol., vol. 31, no. 8, pp. 1733-1746, Aug. 2005, doi: 10.1007/s10886-005-5923-8.

[24] D. G. James and T. S. Price, 'Field-testing of methyl salicylate for recruitment and retention of beneficial insects in grapes and hops', J. Chem. Ecol., vol. 30, no. 8, pp. 1613-1629, 2004.
[25] D. G. James, 'Methyl salicylate is a field attractant for the goldeneyed lacewing, Chrysopa oculata', Biocontrol Sci. Technol., vol. 16, no. 1, pp. 107-110, Feb. 2006, doi: 10.1080/09583150500188510.

[26] R. E. Mallinger, D. B. Hogg, and C. Gratton, 'Methyl Salicylate Attracts Natural Enemies and Reduces Populations of Soybean Aphids (Hemiptera: Aphididae) in Soybean Agroecosystems', J. Econ. Entomol., vol. 104, no. 1, pp. 115-124, Feb. 2011, doi: $10.1603 / \mathrm{EC} 10253$

[27] J. Hardie, R. Isaacs, J. A. Pickett, L. J. Wadhams, and Woodcock, 'Methyl salicylate and (-)-(1R,5S)-Myrtenal are plantderived repellents for black bean aphid, Aphis fabae scop. (Homoptera: Aphididae)', J Chem Ecol, vol. 20, pp. 2847-2855, 1994.

[28] D. Jie, L. I. U. Ying-jie, L. I. Pei-ling, L. I. N. Fang-jing, C. Ju-lian, and L. I. U. Yong, 'Ecological effects of wheat-oilseed rape intercropping combined with methyl salicylate release on Sitobion avenae and its main natural enemies.', Yingyong Shengtai Xuebao, vol. 23, no. 10, 2012.

[29] V. Ninkovic, E. Ahmed, R. Glinwood, and J. Pettersson, 'Effects of two types of semiochemical on population development of the bird cherry oat aphid Rhopalosiphum padi in a barley crop', Agric. For. Entomol., vol. 5, no. 1, pp. 27-34, 2003.

[30] T. A. L. Snoeren, R. Mumm, E. H. Poelman, Y. Yang, E. Pichersky, and M. Dicke, 'The Herbivore-Induced Plant Volatile Methyl Salicylate Negatively Affects Attraction of the Parasitoid Diadegma semiclausum', $J$. Chem. Ecol., vol. 36, no. 5, pp. 479-489, 2010, doi: 10.1007/s10886-010-9787-1.

[31] E. Norin, 'Methyl salicylate production by the fungus Ophiostoma pluriannulatum isolated from Pine Weevil frass', KTH KEMITEKNIK HÖGSKOLEINGENJÖRSUTBILDNINGE N, Stockholm, 2011.

[32] R. Groux, O. Hilfiker, C. Gouhier-Darimont, M. F. G. V. Peñaflor, M. Erb, and P. Reymond, 'Role of Methyl Salicylate on Oviposition Deterrence in Arabidopsis thaliana', J. Chem. Ecol., vol. 40, no. 7, pp. 754-759, Jul. 2014, doi: 10.1007/s10886014-0470-9.

[33] E. H. Koschier, D. Hoffmann, and J. Riefler, 'Influence of salicylaldehyde and methyl salicylate on post-landing behaviour of Frankliniella occidentalis Pergande', J. Appl. Entomol., vol. 131, no. 5, pp. 362-367, Jun. 
2007, doi: $\quad 10.1111 /$ j.14390418.2007.01191.x.

[34] E. Allsopp, G. J. Prinsloo, L. E. Smart, and S. Y. Dewhirst, 'Methyl salicylate, thymol and carvacrol as oviposition deterrents for Frankliniella occidentalis (Pergande) on plum blossoms', Arthropod-Plant Interact., vol. 8, no. 5, pp. 421-427, Oct. 2014, doi: 10.1007/s11829-014-9323-2.

[35] A. de H. Maia, A. J. Luiz, and C. Campanhola, 'Statistical inference on associated fertility life parameters using jackknife technique: computational aspects', J. Econ. Entomol., vol. 93, no. 2, pp. 511$518,2000$.

[36] M. M. Gardiner et al., 'Landscape diversity enhances biological control of an introduced crop pest in the north-central USA', Ecol. Appl., vol. 19, no. 1, pp. 143-154, 2009.
[37] A. R. War, H. C. Sharma, M. G. Paulraj, M. Y. War, and S. Ignacimuthu, 'Herbivore induced plant volatiles: Their role in plant defense for pest management', Plant Signal. Behav., vol. 6, no. 12, pp. 1973-1978, Dec. 2011, doi: 10.4161/psb.6.12.18053.

[38] Z. R. Khan, D. G. James, C. A. O. Midega, and J. A. Pickett, 'Chemical ecology and conservation biological control', Biol. Control, vol. 45, no. 2, pp. 210-224, May 2008, doi: 10.1016/j.biocontrol.2007.11.009.

[39] D. F. Mayer, 'Effects of methyl salicylate on honey bee ( Apis mellifera L.) foraging', $N$. Z. J. Crop Hortic. Sci., vol. 25, no. 3, pp. 291-294, Sep. 1997, doi: 10.1080/01140671.1997.9514018. 